\title{
Endemic Amami Jay, invasive Small Indian Mongoose, and other alien organisms: a new century investigation of island aliens towards improved ecosystem management
}

\author{
K. Ishida ${ }^{1,5} \cdot$ K. Murata ${ }^{2}$ I. Nishiumi ${ }^{3} \cdot$ Y. Takahashi ${ }^{4} \cdot$ M. Takashi ${ }^{5}$
}

Received: 26 February 2015/Revised: 19 May 2015/Accepted: 26 May 2015/Published online: 24 June 2015

(C) The Author(s) 2015. This article is published with open access at Springerlink.com

\begin{abstract}
The Amami Islands in southern Japan host many endemic species, including Amami Jay (Garrulus lidthi). Following the introduction of Small Indian Mongoose (Herpestes auropunctatus) in 1979, populations of Amami Rabbit (Pentalagus furnessi), Amami Woodcock (Scolopax mira), Amami Ishikawa's Frog (Odorrana splendida), and other endemic species declined in the 1990s, as the mongoose expanded its population. A mongoose control project since 2000 successfully reduced the mongoose population to a very low density by 2014 , resulting in the initial recovery of severely affected animal populations. Amami Jay was removed from Japan's endangered species list in 2008. However the population and range of Amami Jay are still small (ca. 700 pairs, sometimes with other family member(s), in $700 \mathrm{~km}^{2}$ ), and other invasive species, such as cats and black rats, continue to damage the native ecosystem. Additionally there is a constant threat of new invasions to the Amami Islands. Our research shows that Amami Jay breeding success depends on the dominant oak (Castanopsis sieboldii) acorn production as much as predation. Therefore conservation plans should consider both short- and long-term effects and potential interaction by both invasive species
\end{abstract}

Communicated by E. Matthysen.

K. Ishida

ishiken@es.a.u-tokyo.ac.jp

1 The University of Tokyo, Tokyo, Japan

2 College of Bioresource Sciences, Nihon University, Fujisawa, Japan

3 National Museum of Nature and Science, Tokyo, Japan

4 Ueno Zoo, Tokyo, Japan

5 Amami Ornithologists' Club, Naze, Japan and other natural factors. Understanding the Amami Jay population dynamics and sustainability from the multiple view points of, such as, population ecology, disease ecology, genetics, and also with ex situ conservation efforts as they relate to invasive species demands, will sophisticate our ecosystem research and management. We discuss how this endeavor of ours might develop as a model activity for maintaining biodiversity under threat from multiple invasive species.

Keywords Amami Islands - Amami Jay - Small Indian Mongoose $\cdot$ Ecosystem management $\cdot$ Disturbance

\section{Introduction}

Islands are hot spots of evolution (MacArthur and Wilson 1967; Whittaker and Fernández-Palacios 2007), and endemic species most of which are small in number and vulnerable against environmental change. Island species populations basically fluctuate dynamically with their normal environment (Whittaker and Fernández-Palacios 2007; Grant and Grant 2014). Invasive species bring one of the most significant environmental changes (Elton 1958). Introduced mammal predators and infectious disease have severely damaged island bird populations or caused their extinction (Courchamp et al. 2003; Kratt et al. 2009). The impacts of biological invasions are usually synergistic and complex on most larger islands with higher biodiversity (Courchamp et al. 2003). Habitat loss and exploitation, the two other most important drivers of extinction, are anthropogenic and natural disturbances together, and man is most invasive. On the other hand, there is also natural disturbance (Begon et al. 2005). Understanding these factors we must consider both anthropogenic and natural 
disturbances together to conserve most island species and their habitat systematically.

Islands in the Pacific Ocean have included sites of longstanding biological studies of organisms, especially on Hawaii and the Galapagos Islands (Kratt et al. 2009; Grant and Grant 2014; Arcilla et al. 2015). Japanese archipelagos and neighboring islands located in the northwest Pacific form a biodiversity hot spot (and feature great linguistics diversity; Gorenfloa et al. 2012), yet bird studies in this Far East region are still relatively nascent. Amami-oshima Island is located here. There are many endemic organisms, including birds such as Amami Jay (Garrulus lidthi), Amami Thrush (Zoothera major), Amami Woodpecker (Dendrocopos owstoni), Amami Woodcock (Scolopax mira), and other vertebrates such as Amami Rabbit (Pentalagus furnessi), Amami Spiny Rat (Tokudaia osimensis), Ryukyu Long-haired Rat (Diplothrix legata), Otton Frog (Babina subaspera), and Amami Ishikawa's Frog (Odorrana splendida).

The Small Indian Mongoose (Herpestes auropunctatus) was introduced to Amami-oshima in 1979 for the control of native Habu Viper (Protobothrops flavoviridis) and the alien rat (Rattus rattus), and increased its population and distribution in the 1990s (Fig. 1). There are also feral cats (Felis silvestris), goats (Capra hircus), many other invasive organisms, and the possible constant threat of other invasions. This area is a major migration route of birds and butterflies, and there is a significant international trade and tourism from East Asia, with its rapidly growing human population and economies. To conserve endemic island

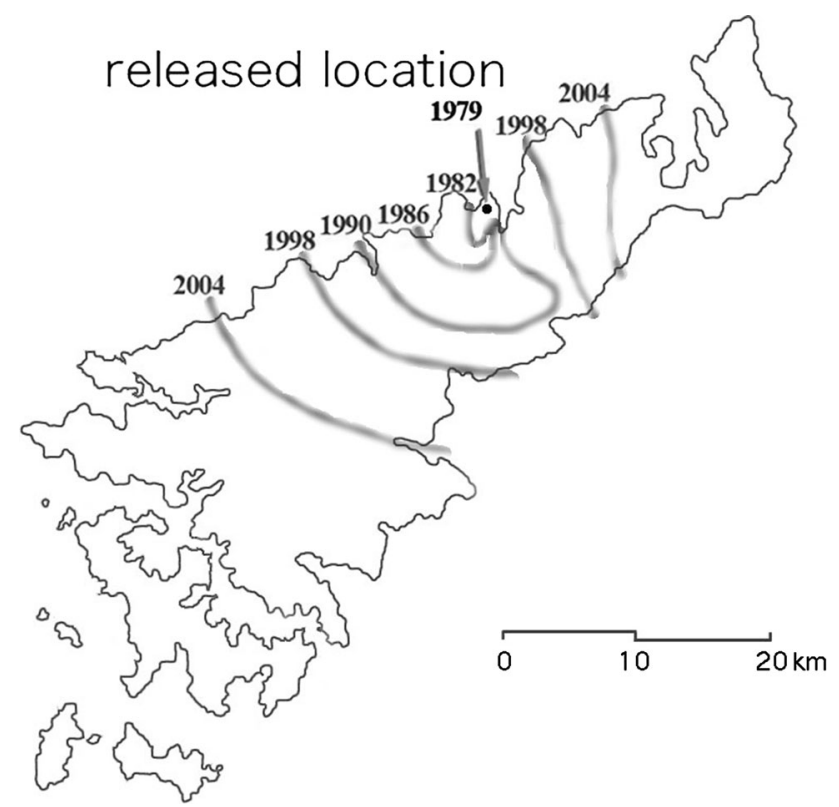

Fig. 1 Location of Amami-oshima Island and the history of the Small Indian Mongoose distribution species in this kind of complex and diverse ecosystem, investigation of a single issue such as endangered and/or flagship species is not enough (Ishida et al. 2003; Simberloff 1998). Instead we expect the study of ecosystem dynamics with several significant (keystone-like) and indicator species and with multiple aims (Table 1) will contribute for the sustainable biodiversity of the island.

Amami Jay is omnivorous and a top predator. The fact that it depends on the dominant oak acorn production means that Amami Jay can be a good indicator species to monitor the forest ecosystem dynamics and biodiversity. Our goals are to determine the key factors driving natural population dynamics and the processes for each target species, such as oak masting for the Amami Jay.

\section{Materials and methods}

\section{Amami Jay and study sites}

Amami Jay is endemic to Amami-oshima Island, $712 \mathrm{~km}^{2}$ in area, $300 \mathrm{~km}$ southwest from Kyushu Island, Japan, and a couple of adjacent islets $\left(+172 \mathrm{~km}^{2}\right)$. About $85 \%$ of the islands are covered with native evergreen broadleaf forest (Kagoshima Prefecture 2012). Observation of Amami Jay breeding ecology with 10 nest boxes has been conducted since 2003, and then with 20 nest boxes since 2009, at the secondary forest of Ichiribaru district, northern Amamioshima Island $\left(28^{\circ} 24^{\prime} 38^{\prime \prime} \mathrm{N}, 129^{\circ} 36^{\prime} 42^{\prime \prime}\right)$. The nest box has two entrances on opposite sides, low and high. Floor size is $30 \mathrm{~cm} \times 30 \mathrm{~cm}$ and height is $45 \mathrm{~cm}$. They are attached at the top of a 2-m smooth plastic column to prevent

Table 1 Possible conservation factors relating to Amami Jay population sustainability

\begin{tabular}{|c|c|c|c|}
\hline Factors & Tactic term $^{\mathrm{a}}$ & Priority $^{\mathrm{b}}$ & This study \\
\hline Habitat loss & Middle & High & Indirect \\
\hline Exploitation & $-^{\mathrm{c}}$ & Low & Protected \\
\hline Invasive predator & Long & High & Direct \\
\hline Climate change & Long & Middle & Indirect \\
\hline Acorn dynamics & Short & High & Direct \\
\hline Other resources & Short & Low & Indirect \\
\hline Competition & Middle & Middle & Indirect \\
\hline Pathogen & Short & Middle & Temporal \\
\hline Parasite & Short & Middle & Temporal \\
\hline Gene diversity & Long & Middle & Temporal \\
\hline Ex situ conservation & Long & Middle & Direct \\
\hline \multicolumn{4}{|c|}{$\begin{array}{l}\text { a Supposed observation term length in Amami birds; } \\
\text { long }=30-100 \text { years, middle }=10-40 \text { years, short }=1-20 \text { years } \\
\text { b Priority for Amami Jay conservation, in this period (2000-2050) } \\
\text { c Exploitation includes various kinds of wide term length, depending } \\
\text { on the culture and society systems, and international relations }\end{array}$} \\
\hline
\end{tabular}


predation by snakes and mammals from the ground, and the branches around the nest boxes are removed to decrease the chance of predation from above. The nest boxes had been improved according to our observations since 1997 (Ishida et al. 1998). The old nest materials are removed clearly during the winter before the jay starts their nest building in January. Those nest boxes are moved to another place when they are assumed to have been disturbed by predators in the previous breeding season. Since 2010, automatic interval cameras (Pentax Optio W60) have been fixed on the roof of nest boxes to record the breeding stages of the jay from above the nest. Photos were taken every 30-90 min. Till 2009, we checked inside the nest box every week during the breeding season from January to May.

\section{Blood samples for parasitic and genetic analysis}

Most of the nestlings were identified by a metal number ring from the Ministry of the Environment. Nestling blood was sampled from the brachial vein. Blood films were made at once, which were air-dried, fixed in methanol, and stained with Giemsa solution and then examined by microscopy for haemosporidian parasites. The blood samples were also preserved in a micro tube with $0.2 \mathrm{ml}$ ethanol. DNA was extracted from them and the nested PCR reaction targeted a partial region of the mitochondrial cytochrome $b$ (cytb) genes of avian malaria parasites (Plasmodium and Haemoproteus) was performed. Phylogenetic analysis was performed using MEGA 4 (Tamura et al. 2007) and distance analyses were performed using the Kimura 2-parameter model with the neighbor-joining (NJ) method. In this paper, we show the results of the samples for 3 years of 2009-2011.

Blood samples of 33 individuals (28 adults; 24 captured with mist nets, 1 museum specimen, 3 Ueno Zoo stock, and 5 nestlings from nest boxes mainly in 2009-2011) were examined for microsatellite heterogeneity. Thirty-two were from Amami-oshima Island, of which 22 were from the northern area and 10 from the southwest, and only one adult bird was from Kakeroma-jima. Twenty microsatellite loci, which had more than four alleles from 100 loci examined in Siberian Jay (Perisoreus infaustus), were selected to test Amami Jay molecular diversity preliminary. We followed the protocol of Jaari et al. (2008).

\section{Acorn production}

Acorn production of oaks has been monitored with ten bucket-traps placed at both Kinsakubaru $\left(28^{\circ} 20^{\prime} 5^{\prime \prime} \mathrm{N}\right.$, $\left.129^{\circ} 27^{\prime} 10^{\prime \prime}\right)$ and Kawauchi $\left(28^{\circ} 18^{\prime} 31^{\prime \prime} \mathrm{N}, 129^{\circ} 24^{\prime} 30^{\prime \prime}\right)$ forest since 2003. The open diameter of the traps is $50 \mathrm{~cm}$. The oak tree (Castanopsis sieboldii) is a dominant species in most areas of natural old forest on Amami Islands. It occupied 461 of 2928 trees $(\mathrm{GBH}>15 \mathrm{~cm}, 15.7 \%)$ and 30.02 of $58.24 \mathrm{~m}^{2}$ with basal area (at breast height, $51.6 \%$ ), in our vegetation survey with 1 ha square plot at an old and typical evergreen broadleaf natural forest at Kinsakubaru National Forest in September 2005. The oaks produced more than $300 \mathrm{~kg}$ acorns/ha in the rich crop year of 2007. Monitoring with 25 circle litter traps of $0.5 \mathrm{~m}^{2}$ mouth area (total $12.5 \mathrm{~m}^{2}$ ) at the 1-ha vegetation plot every half a month since August 2005, we found that almost all sound acorns were matured and fell to the ground during November and December, numbering 376,000 with a total weight of approximately $240 \mathrm{~kg} / \mathrm{ha}$ at the plot (Ishida and Kawaguchi, unpublished data). The acorns were partly foraged and harvested by Amami Jays, Varied Tits (Parus varius), several insects, and maybe rats on the branches before they fell.

\section{Small Indian Mongoose}

A small number of the invasive mongoose were released by unauthorized persons at Naze City in 1979; this increased its population and distribution on Amami-oshima Island, mainly toward the southwest, where the area is larger within the island and there is more native habitat (Fig. 1). About $1 \mathrm{~km} /$ year, recorded here, is a typical expansion speed in mongoose-invaded areas. The Ministry of the Environment, Japan, started the mongoose control in 2000. The total annual effort approaches two million trap-days since 2005 (Fig. 2), and three mongoose control dogs and handlers have been active to detect and capture the mongoose since 2010 (Ministry of the Environment, Japan

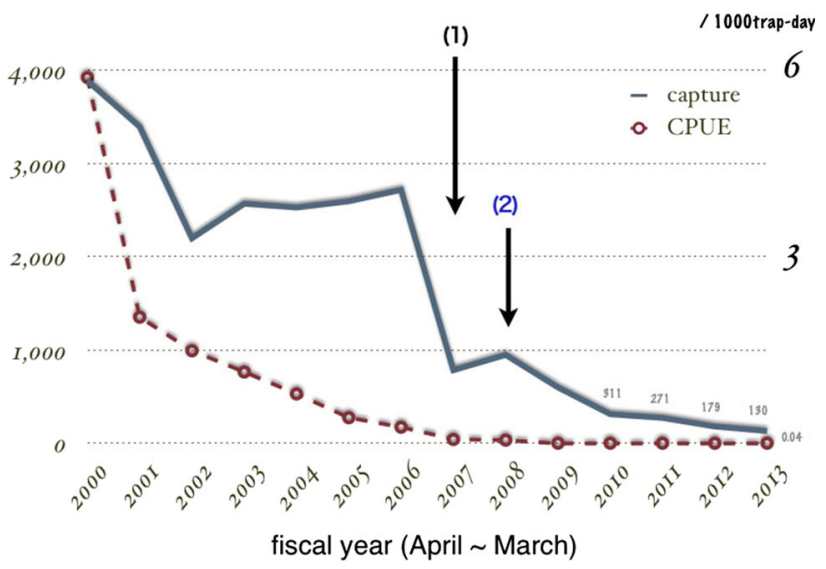

Fig. 2 Captured number of Small Indian Mongoose and capture rate per unit effort (1000 trap-days) in each fiscal year of mongoose control project, the Ministry of the Environment, Japan. Arrow (1) indicates the timing when the Amami Mongoose Busters (specialist group for mongoose capture) covered the whole distribution area, and arrow (2) when the Amami Jay was removed from the Japanese Red List. CPUE Catch Per Unit Effort 
2014). More than 40 permanent staff, the Amami Mongoose Busters, have been implementing control to capture mongoose. Fukasawa et al. (2013) estimated the mongoose population trends in the past with Bayesian statistics, based on the capture rates, a priori hypothesis, and prior probability. Trends of the estimated population change through 1979-2011, from dozens to 10,000, and then reduced to a couple of hundred [less than 200 annual captures in 2012 and later, and the estimation of 169 (95\% CI 42-408) by 2011], seems to be realistic, but there is uncertainty due to trap shyness (Barun et al. 2011). Partial recovery of several indigenous vertebrates has been subsequently reported after the mongoose decline (Watari et al. 2013; Amami Ornithologists' Club 2013, unpublished data).

\section{Results}

\section{Acorn production, Amami Jay breeding, and ecosystem dynamics}

During 11 years from 2003 to 2013, we observed two consequent poor acorn crop periods (2004-2005 and 2012-2013), and acorn crop was rich in 2003, 2007, and 2010 (Fig. 3). We know it was also rich in 1997 and 2000 from general observations. The acorn production among the Amami Islands or even in a wider range from Kyushu Island to Ryukyu Islands, is nearly synchronous, though there is some variation (Suzuki et al. 2012). Amami Jay breeding success has been fluctuating over the years, and it depended mostly on the acorn production. Acorn production, predation, and competition in higher density seasons are all factors that may influence the jay breeding success (Fig. 4). In the later year of the poor-acorn production

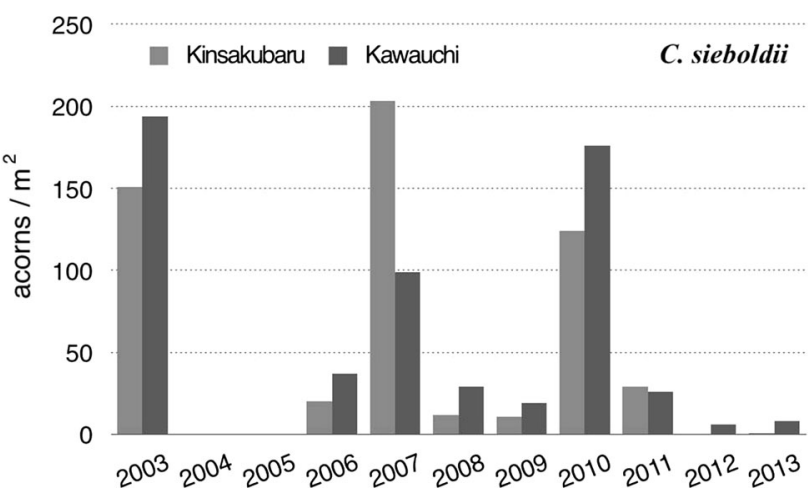

Fig. 3 Dynamics of acorn production by an oak, C. sieboldii, monitored with ten 50-cm-diameter mouth bucket traps at each site. It takes 1.5 years for the acorns to mature from the flowers. Some of them stop immature, or empty even when they grow into a mature size. Amami Jay forages on the acorn on both branches and the ground sequence, the breeding dates of the Amami Jay population were delayed (Table 2). Even in the worst season, however, some pairs produced successful clutches, sometimes twice at the same nest box with the normal three or four fledglings. The temporal result during 12 breeding seasons indicates that large acorn production is a fundamental driver of Amami Jay's higher breeding performance, and acorn production sequence is also affected by the moderate jay breeding density through predation and competition (Fig. 5).

\section{Avian malaria parasites' infection and genetics of Amami Jay}

During the 3-year study period, 30 adults and 69 nestlings of Amami Jay were examined. A total of 12 of 30 adult birds $(40 \%)$ were PCR positive for avian malaria parasites over the 3 years, and no positive cases were found in nestlings (Table 3a). Comparing to the results for the small samples of other birds (Table 3b), collected in Amami islands, the prevalence of avian malaria parasites in adult Amami Jay is not high, though it is higher than most of those at central high mountain bird populations (Imura et al. 2012). A temporal phylogenetic analysis of avian malaria parasites revealed that $c y t b$ sequences from two of the seven Amami Jay samples were close to those from birds in Myanmar, one was close to those from birds in the other area of Japan, and the others were identical among Amami birds.

Seven among 20 tested microsatellite loci were polymorphic without deviation from Hardy-Weinberg equilibrium. The numbers of alleles in each microsatellite locus

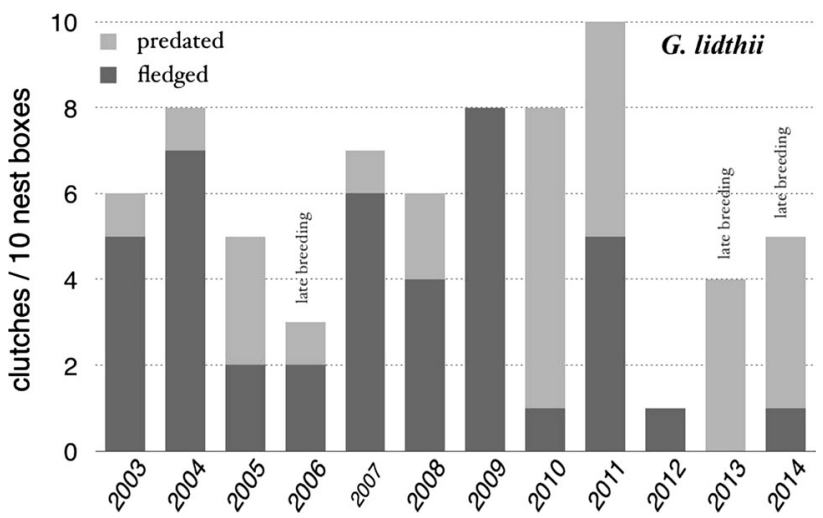

Fig. 4 Breeding performance of the Amami Jay, estimated by the number of egg-laying clutches and fledged at the ten nest boxes in Ichiribaru district, Amami-oshima Island. Clutch number decreases after poor or no acorn production, and the breeding success of the population is not directly dependent on the acorn-rich condition, as the disadvantages caused by predation and competition are higher sometimes, probably while the Amami Jay breeding density is high (it was most salient in 2010) 
Table 2 Breeding dates of Amami Jay: earliest and latest clutch (first egg laid), hatch, fledge dates in each year

\begin{tabular}{lrrrrrrrrrrrr}
\hline Year & 2003 & 2004 & 2005 & 2006 & 2007 & 2008 & 2009 & 2010 & 2011 & 2012 & 2013 & 2014 \\
\hline Earliest egg & 34 & 25 & 85 & 43 & 49 & 26 & 24 & 26 & 25 & 40 & 66 & 64 \\
Latest egg & 56 & 62 & 128 & 81 & 79 & 41 & 65 & 41 & 56 & 112 & 103 & 95 \\
Earliest hatch & 85 & 62 & 102 & 81 & 79 & 46 & 43 & 33 & 43 & 60 & 83 & 83 \\
Latest hatch & 101 & 90 & 128 & - & 91 & 83 & 70 & 83 & 76 & 131 & 126 & 115 \\
Earliest fledge & 85 & 76 & 115 & 81 & 84 & 70 & 70 & 70 & 78 & 83 & 104 & 105 \\
Latest fledge & 101 & 120 & 153 & 118 & 93 & 100 & 112 & 100 & 111 & 155 & 138 & 131 \\
\hline
\end{tabular}

The dates were estimated from the observation of every week till 2009, then interval pictures, taken every 30-90 $\mathrm{min}$, were referred to later

January 1 = day 1; 2003-2008, 10 nest boxes; 2009-2014, 20 nest boxes

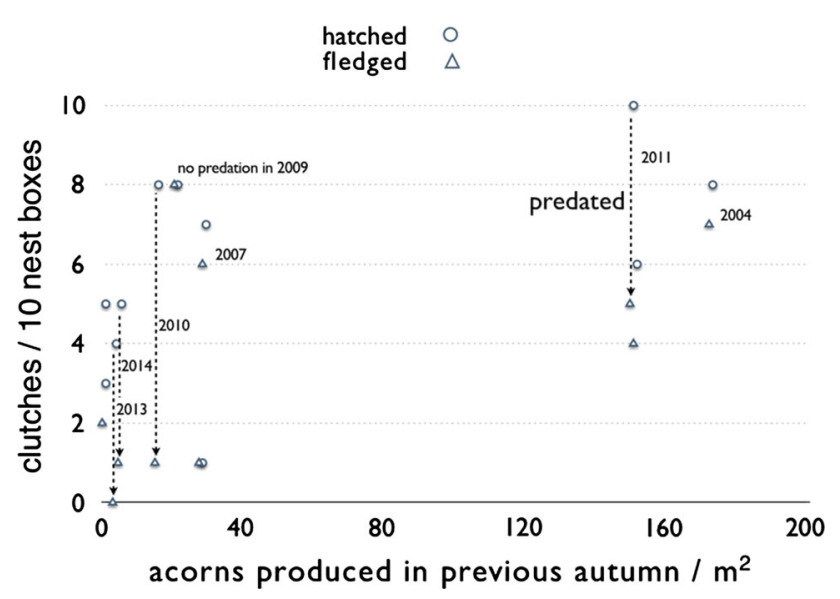

Fig. 5 Relation between previous autumn oak acorn production and the fledged number of clutches. Acorn production is shown as collected density $\left(/ \mathrm{m}^{2}\right)$ with 20 traps of two sites, shown as the averages of the two plots. Both total number of clutches (at least one egg laid, circle) and fledged clutch number (triangle) are shown, decrease between the two indicates predation of eggs or nestlings

were 13 (f 9) in SJ059, 6 (f 4) in SJ083, 4 (f 9) in SJ014, 4 (f 7) in SJ101, 3 (f 8) in SJ066, 2 (f 6) in SJ065, 2 (f 7) in SJ106, and the average number of alleles was 4.86 (f 7.14). Comparing the numbers to those in Siberian Jay in Finland (f $\mathrm{n}$ in parentheses; Jaari et al. 2008), Amami Jay has fewer alleles than Siberian Jay, though the sample size is still small. The alleles found in the loci of SJ083 (size of allele 264) and SJ014 (270) from a Kakeroma-jima individual were rare haplotypes in those among Amami-oshima individuals.

\section{Discussion}

Through our 12-year observation of Amami Jay nest ecology and oak acorn production, we detected the relationship between jay population and forest ecosystem dynamics. A few decades of study is not sufficient to understand ecosystem processes as they relate to bird populations; 40 years may be a minimum (Grant and Grant 2014). Mougi and Kondoh (2014) showed that predatorprey trophic cascades are an important factor for the preservation of species richness and stability of an organism community. Ecosystems are complex and dynamic, especially those of island forests. So our study of Amami Jay is still in development.

The invasive mongoose and invasive snake (Boiga irregularis) controls for the recovery of the Okinawa Rail (Gallirallus okinawae) and the restoration of the Guam Rail (G. owstoni, Arcilla et al., current issue) indicate that in situ and ex situ conservation activity requires substantial (Haig et al. 1990), sustained effort and we have some experience with Amami Jay to achieve our goals. A model species study and trials of both in situ and ex situ with a native population are indispensable for the future island biodiversity conservation, and Amami Jay is one of the candidates for this kind of study (Table 4). We collect only one smallest nestling for the zoo stock from each nest, considering genetic biodiversity, for which information on genetic structure in the species will also contribute significantly (Tracy et al. 2011). Ex situ conservation activities assume the possibility of future restoration from the captive population to the native wild. Reserving the original genetic diversity is one of the important issues. Armstrong and Seddon (2008) also noted on this concern. Much is left to investigate and evaluate; it should be useful to study it in Amami Jay, as it is endemic only to Amami Islands and the whole gene pool can be within the scope of our work.

The common avian malaria species with the birds of Myanmar and other Japanese areas found in Amami Jay blood samples indicates their interactions with migratory birds within this wide area. We often found a rare beetle, Protaetia lewisi, several ants (Formicidae), and cockroaches (Blattellidae) in the Amami Jay nests. Nestlings often have several parasitic leaches (Metastigmata and Prostigmata) and/or louse flies (Hippoboscidae). Nasu et al. (unpublished data) have been investigating the invertebrate community in the Amami Jay nest materials since 2011, and found also Lepidoptera and other many kinds. There 
Table 3 Avian malaria-positive individual numbers in each site of Amami Jay (a) and other birds (b)

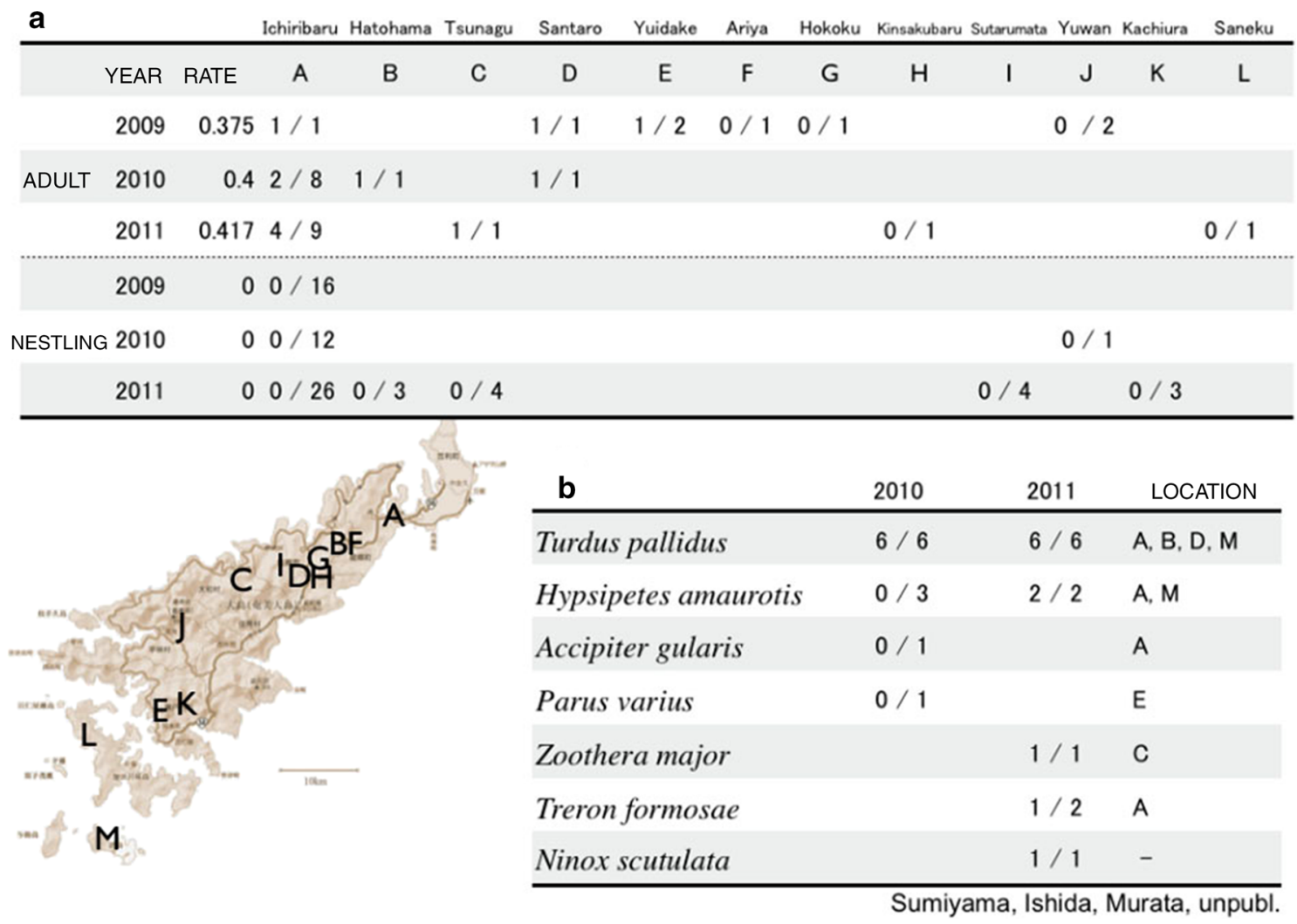

are some parasites of the nestlings and a small community at the bird nest. Our work is still ongoing, but this kind of multiple ecosystem study is important and practical to protect species from anthropogenic decline and extinction. Monitoring this kind of environment and species interaction can provide basic information to help preserve or restore the bird nest conditions and prepare for invasive parasites, e.g., Cimadom et al. (2014) showed that a recently introduced fly (Philornis downsi) had damaged the birds on the Galápagos. Monitoring the normal parasite

Table 4 Ex situ progress of Amami Jay at Ueno Zoo and Hirakawa Zoo

\begin{tabular}{|c|c|c|c|c|c|}
\hline & Collect & Survivor & Pair & Clutch & Fledge \\
\hline 2009 & $3 \widehat{\circ} 1$ 우 & & & & \\
\hline 2010 & $3 \hat{\jmath}$ & $6 \hat{\jmath}$ & & & \\
\hline 2011 & & $6 \hat{3}$ & & & \\
\hline 2012 & $2 \hat{\jmath} 1$ ㅇ & $6 \widehat{0} 1$ 우 & & & \\
\hline 2013 & $1 \hat{\jmath} 4$ 우 & $5 \widehat{~} 5$ 우 & 1 & & \\
\hline 2014 & & $4 \overbrace{}^{1} \overbrace{}^{\mathrm{a}}$ & 2 & $2^{b}$ & 0 \\
\hline
\end{tabular}

${ }^{a}$ A male was transferred to Hirakawa Zoo, Kagoshima city

b Two chicks died early in one clutch community in the bird nests may contribute to find invasions of parasites in the future. Fraser et al. (2014) introduced an example of natural invasion of a plover (Vanellus miles novaehollandiae) which also changed the wader community in New Zealand. Also, restored male stokes (Ciconia boyciana) from Toyooka City, Hyogo, have been staying on Amami-oshima and Tokunoshima Islands for more than a year, and there is some possibility of natural invasion.

Through the dramatic density decrease of the invasive mongoose on Amami-oshima Island, the restoration of most native animal communities is apparent (Fukasawa et al. 2013; Watari et al. 2013; Leadley et al. 2014). It was achieved with many small innovations in trap structure and trapping techniques during the last decade (Simberloff 2009). The Small Indian Mongoose is a worldwide island invasive and we have very few examples of successful control or eradication from large islands (Barun et al. 2011). Ministry of the Environment, Japan (2013) details the mongoose eradication project during 2013-2022 fiscal years and targeting the mongoose eradication from the island. It is actually, however, difficult to achieve mongoose eradication on an island with plenty of native species including several rats, a rabbit, birds, and frogs in a forest 
ecosystem. So we have to continue monitoring the ecosystem with several indicator and flagship species.

Simberloff (1998) discussed how to monitor and manage biodiversity, and compared the advantages and disadvantages of several conservational and/or ecological concepts-indicator, umbrella, flagship, keystone species, and ecosystem management, for preservation of more native or original organisms or less extinction of them. He thought using indicator species was the best approach, but it was often impossible to find a good one or define the fittest one in each ecosystem or habitat. Umbrella and flagship species are usually a political or subjective (preferred or charismatic for the public) concept, not a scientific one. So Simberloff thought a small number of them might sacrifice many other species, and costs were often high. Blackburn (2009) wrote: "we have failed to make progress (in these 80 years)", and we agree with him. We have not yet understood the processes of invasion biology and failed to describe patterns clearly. We will continue with more research to determine the processes between Amami Jay and acorn production, and the relationship among the indicator species. We hope our trials on Amamioshima, including the Amami Jay study and mongoose control, will contribute to the solutions.

Acknowledgments This study was partially supported by JSPS KAKENHI Grant Number 18310151, 90192484, 21651100, the University of Tokyo, Nippon University, and Gorilla Fund of Tokyo Zoological Park Society. Our fieldwork was supported by Nagai Y, Torikai H, and other members of Amami Ornithologists' Club. The study on avian malaria parasites was supported by Drs. Imura T, Sumiyama D, and Sato Y of the College of Bioresource Sciences, Nihon University. Amami Wildlife Conservation Center of the Ministry of the Environment, Amami Office of Japan Wildlife Research Center, and Ueno Zoo helped us in a various ways, including supplying information about the mongoose control project in Japan, transportation of ex situ population founder nestlings, providing facilities to perform the field works, and so on. The two symposium convenors, Drs. Arcilla N and Lepczyk C, and the two referees, kindly supported us to arrange our presentation and improve this manuscript, all the way. We sincerely thank them all.

Open Access This article is distributed under the terms of the Creative Commons Attribution 4.0 International License (http://creativecommons.org/licenses/by/4.0/), which permits unrestricted use, distribution, and reproduction in any medium, provided you give appropriate credit to the original author(s) and the source, provide a link to the Creative Commons license, and indicate if changes were made.

\section{References}

Amami Ornithologists' Club (2013) Results of the Amami thrush survey in March 2013 (in Japanese). http://www.synapse.ne.jp/ $\sim$ lidthi/AOC/news/ootorahoukoku13.html. Accessed 1 Nov 2014

Arcilla N, Choi CY, Lepczyk CA, Ozaki K (2015) Recent research on invasive species and Pacific island bird conservation, featuring case studies of Swinhoe's storm petrel and Okinawa rail (this volume)

Armstrong DP, Seddon PJ (2008) Directions in reintroduction biology. Tree 23(1):20-25

Barun A, Hanaon CC, Campbell KJ, Simberloff D (2011) A review of small Indian mongoose management and eradications on islands. In: Veitch CR, Clout MN, Towns DR (eds) Island invasives: eradication and management. IUCN, Auckland, pp 17-25

Begon M, Townsend CR, Harper JL (2005) Ecology, from individuals to ecosystems. Wiley, Hoboken

Blackburn TM (2009) Avian invasion. Oxford University Press, London

Cimadom A, Tebbich S, Fessl B, Hood-Novotny R (2014) Behavioural changes in an invasive parasitic fly and its avian hosts, the Darwin's finches. In: S11-4, XXVIth international ornithological congress (Ornithological Science 13 Suppl.), Tokyo, p 53

Courchamp F, Chapuis J-L, Pascal M (2003) Mammal invaders on islands: impact, control and control impact. Biol Rev 78:347-383

Elton CS (1958) Ecology of invasion by animals and plants. Methuen, London

Fraser D, Galbraith M, Adams N, Blanchon D (2014) Range expansion of the spur-winged plover (Vanellus miles novaehollandiae) in New Zealand. Notornis 61:43-47

Fukasawa K, Hashimoto T, Tatara M, Abe S (2013) Reconstruction and prediction of invasive mongoose population dynamics from history of introduction and management: a Bayesian state-space modeling approach. J Appl Ecol 50:469-478

Gorenfloa LJ, Romaineb S, Mittermeierc RA, Walker-Painemillad K (2012) Co-occurrence of linguistic and biological diversity in biodiversity hotspots and high biodiversity wilderness areas. PNAS 109:8032-8037

Grant PR, Grant BR (2014) 40 years of evolution: Darwin's finches on Daphne Major Island. Princeton University Press, Princeton

Haig SM, Ballou JD, Derrickson SR (1990) Management options for preserving genetic diversity: reintroduction of Guam rails to the wild. Conserv Biol 4:290-300. doi:10.1111/j.1523-1739.1990. tb00291.X

Imura T, Suzuki Y, Ejiri H, Sato Y, Ishida K, Sumiyama D, Murata K, Yukawa M (2012) Prevalence of avian haematozoa in wild birds in a high-altitude forest in Japan. Vet Parasitol 183:244-248

Ishida K, Takashi M, Ueta M (1998) A breeding record of Lidth's jay in a nest box at a natural forest of Kinsakubaru on Amami Island. Strix 16:148-151 (in Japanese)

Ishida K, Miyashita T, Yamada F (2003) Ecosystem management considering community dynamics, an example of Amamioshima Island. Jpn J Conserv Ecol 8:159-168 (in Japanese with English summary)

Jaari S, Vålimåki K, Merilå J (2008) Isolation and characterization of 100 polymorphic microsatellite loci for the Siberian jay (Perisoreus infaustus). Mol Ecol Resour 8:1469-1474

Kagoshima Prefecture (2012) Summary of Amami Islands, Kagoshima

Kratt TK, Atkinson CT, Banko PC, Jacobi JD, Woodworth BL (2009) Conservation biology of Hawaiian forest birds. Yale University Press, New Haven

Leadley et al (2014) Technical series 78-progress towards the Aichi Biodiversity Targets: an assessment of biodiversity trends, policy scenarios and key actions. Secretariat of the Convention on Biological Diversity; PBL Netherlands Environmental Assessment Agency

MacArthur RA, Wilson EO (1967) The theory of island biogeography. Princeton University Press, Princeton

Ministry of the Environment, Japan (2013) http://kyushu.env.go.jp/ naha/wildlife/data/gairai/boujyo/130425b.html. Accessed 1 Nov 2014 (in Japanese) 
Ministry of the Environment, Japan (2014) http://kyushu.env.go.jp/ naha/pre_2014/0813a.html. Accessed 1 Nov 2014 (in Japanese)

Mougi A, Kondoh M (2014) Stability of competition-antagonismmutualism hybrid community and the role of community network structure. J Theor Biol 360:54-58

Simberloff D (1998) Flagships, umbrellas, and keystones: is singlespecies management passé in the landscape era? Biol Conserv 83(3):247-257

Simberloff D (2009) We can eliminate invasions or live with them. Successful management projects. Biol Invasions 11:149-157

Suzuki SN, Ishihara MI, Nakamura M, Abe S, Hiura T, Homma K, Higa M, Hoshino D, Hoshizaki K, Ida H, Ishida K, Kawanishi M, Kobayashi K, Kuraji K, Kuramoto S, Masaki T, Niiyama K, Noguchi M, Nomiya H, Saito S, Sakai S, Sakimoto M, Sakio H, Sato T, Shibano H, Shibata M, Suzuki M, Takashima A, Tanaka H, Takagi M, Tashiro N, Tokuchi N, Yoshida T, Yoshida Y
(2012) Nation-wide litter fall data from 21 forests of the Monitoring Sites 1000 Project in Japan. Ecol Res 27:989-990. doi:10.1007/s11284-012-0980-2

Tamura K, Dudley J, Nei M, Kumar S (2007) MEGA4: molecular evolutionary genetics analysis (MEGA) software version 4.0. Mol Biol Evol 24:1596-1599

Tracy LN, Wallis GP, Efford MG, Jamieson IG (2011) Preserving genetic diversity in threatened species reintroductions: how many individuals should be released? Anim Conserv 14:439-446

Watari Y, Nishijima S, Fukasawa M, Yamada F, Abe S, Miyashita T (2013) Evaluating the "recovery level" of endangered species without prior information before alien invasion. Ecol Evol. doi:10.1002/ece3.863

Whittaker RJ, Fernández-Palacios JM (2007) Island biogeography, ecology, evolution and conservation. Oxford University Press, Oxford 